\title{
Association between tocilizumab treatment and clinical outcomes of COVID-19 patients: a systematic review and meta-analysis
}

\author{
Jingwen Peng ${ }^{1,3}$, Xiaodong She ${ }^{1,3}$, Huan Mei $^{1,3}$, Hailin Zheng ${ }^{1,3}$, Meihua Fu ${ }^{1,3}$, Guanzhao Liang ${ }^{1,3}$, \\ Qiong Wang ${ }^{1,3}$, Weida Liu ${ }^{1,2,3}$ \\ ${ }^{1}$ Department of Medical Mycology, Institute of Dermatology, Chinese Academy of Medical Science and Peking \\ Union Medical College, Nanjing 210042, Jiangsu, People's Republic of China \\ ${ }^{2}$ Center for Global Health, School of Public Health, Nanjing Medical University, Nanjing 211166, Jiangsu, People's \\ Republic of China \\ ${ }^{3}$ Jiangsu Key Laboratory of Molecular Biology for Skin Diseases and STIs, Nanjing 210042, Jiangsu, People's \\ Republic of China
}

Correspondence to: Weida Liu; email: liuwd@pumcderm.cams.cn

Keywords: tocilizumab, COVID-19, efficacy, meta-analysis, randomized controlled trial

Received: July 23, $2021 \quad$ Accepted: December 29, $2021 \quad$ Published: January 17, 2022

Copyright: (C) 2022 Peng et al. This is an open access article distributed under the terms of the Creative Commons Attribution License (CC BY 3.0), which permits unrestricted use, distribution, and reproduction in any medium, provided the original author and source are credited.

\section{ABSTRACT}

To explore and summarize the association between treatment with tocilizumab and clinical outcomes in COVID-19 patients. We performed a systematic review and meta-analysis (10 RCTs including 3378 patients in the tocilizumab group and $\mathbf{3 1 4 2}$ patients in the control group). We systematically searched PubMed and MedRxiv for all RCTs as of June 1, 2021, to assess the benefits and harms of tocilizumab to treat patients with COVID-19. All analyses were carried out using RevMan version 5.4.1. There were nine RCTs published in peer-reviewed journals and one RCTs published as a preprint. The summary RR for all-cause mortality with tocilizumab was $0.89(95 \% \mathrm{Cl}=$ $0.82-0.96, P=0.003)$. There was no significant between-trial heterogeneity $\left(I^{2}=28 \%, P=0.19\right)$. However, all peerreviewed RCTs showed no significant associations between treatment with tocilizumab and reductions in all-cause mortality. We notably found that tocilizumab significantly reduced the rate of intubation or death in patients with COVID-19 with 3 RCTs. Across the 8 RCTs, the summary RR for discharge with tocilizumab was 1.10 (95\% Cl= $1.03-$ $1.16, P<0.00001)$. There was no significant association of tocilizumab with harm on other patient-relevant clinical outcomes, including increasing secondary infection risk, patients of adverse events, or patients of serious adverse events. Tocilizumab significantly increased the rate of hospital discharges in COVID-19 patients. Still, it did not decrease all-cause mortality or increase the risk of secondary infections, patients of adverse events, or patients for serious adverse events. Evidence that tocilizumab affects clinical outcomes in patients with COVID-19 requires further proof.

\section{INTRODUCTION}

Severe acute respiratory syndrome coronavirus 2 (SARS-CoV-2), a novel human pathogen, is one of the most considerable global challenges facing public health and humanity [1-3]. With the development of the coronavirus disease 2019 (COVID-19) pandemic, there has been unwarranted enthusiasm for using tocilizumab [4-12], but the clinical evidence of its benefits or harm is limited.
COVID-19 is associated with dysregulated immune responses and hyper inflammation, including releasing of proinflammatory cytokines and chemokines. It can cause or worsen acute respiratory distress syndrome and multiple organ failure [13-15]. Several scholars have recently suggested that tocilizumab may be positively associated with a lower risk of intubation or death in patients with severe and critically ill COVID-19 pneumonia [11, 13-20]. Inhibitors of Interleukin 6 (IL-6) or its receptor have successfully treated different 
cytokine storm syndromes or powerful chimerical antigen receptor $\mathrm{T}$ cell -mediated cytokine release syndrome [2,13]. The randomized evaluation of the COVID-19 therapy platform (RECOVERY) trial is by far the largest randomized clinical trial (RCT) on COVID-19 treatments [21]. It has provided essential evidence for several promising therapies, including hydroxychloroquine, dexamethasone, lopinavirritonavir, convalescent plasma, and azithromycin.

Given the previously reported RCTs, we conducted the systematic review and meta-analysis $(10$ RCTs including 3378 patients in the tocilizumab group and 3142 in the control group) to explore and summarize the association between tocilizumab treatment and clinical outcomes in COVID-19 patients.

\section{RESULTS}

We noted 39 records in the related databases, registries, and other sources. We included 9 RCTs published in peer-reviewed journals and 1 RCTs published as preprints. Of the ten included RCTs, three were in the USA, two were in India, and one each in France, Italy, Brazil, International, and the UK. Only 1 RCT was prematurely interrupted after an interim analysis for futility (NCT04346355). There were three double-blind RCTs (NCT04356937, NCT04372186, and NCT04320615), whereas the other 7 were openlabel RCTs (CTRI/2020/05/024959, NCT04331808, NCT04346355, NCT04403685, CTRI/2020/05/025369, NCT02735707, and NCT04381936).

From 9 RCTs published in peer-reviewed journals, there were 2404 patients (1048 to placebo together with the standard of care or only standard of care and 1356 randomized to tocilizumab) in our meta-analysis. There were 4116 patients (2094 to the only standard of care and 2022 randomized tocilizumab) in the RECOVERY trial (NCT04381936). Comorbidities at randomization were universal when reported in most studies. Detailed information on patient characteristics was accessible to all RCTs (Table 1 and Supplementary Table 1).

\section{Association of tocilizumab with clinical outcomes}

For all RCTs, the all-cause mortality in patients receiving tocilizumab was $23.98 \%(810 / 3378)$ and $28.74 \%$ (903/3142) in control patients. We found the summary RR for all-cause mortality with tocilizumab was $0.89(95 \% \mathrm{CI}=0.82-0.96, P=0.003)$. There was no significant between-trial heterogeneity $\left(I^{2}=28 \%, P=\right.$ 0.19). However, 9 peer-reviewed RCTs showed that no significant association between tocilizumab treatment and all-cause mortality reduction $(\mathrm{RR}=0.87,95 \% \mathrm{CI}=$ $0.73-1.04, P=0.13$ ).
Three double-blind RCTs received placebo, no significant association between tocilizumab treatment and all-cause mortality reduction $(\mathrm{RR}=1.10,95 \% \mathrm{CI}=$ $0.79-1.54, P=0.57$ ). We notably found that tocilizumab significantly reduced the rate of intubation or death in patients with COVID-19 with 3 RCTs $(\mathrm{RR}=0.85,95 \%$ $\mathrm{CI}=0.78-0.92, \quad P=0.0002) \quad($ Figure $1 \mathrm{~A}, \quad 1 \mathrm{D}$, and Supplementary Figure 1).

We conducted a Begg/Egger test and used a funnel plot to assess the publication bias of our meta-analysis ( $P$-value of publication bias was 0.596). We also performed a sensitivity analysis by omitting one study when calculating the summary results. After eliminating the RECOVERY trial (NCT04381936), the combined OR value and 95\%CI changed from positive to adverse. As the amount of the RECOVERY trial data accounts for $76 \%$ of the total data and the risk of bias in the RECOVERY trial was considered high, which may cause the combined results of the RECOVERY trial to be not very reliable (Supplementary Figure 2).

Across the 8 RCTs, the summary RR for discharge with tocilizumab was 1.10 (95\% CI=1.03-1.16, $P<0.0001)$. Similar results were also observed for the preprint, peerreviewed RCTs, double-blind (placebo plus standard care) and open label RCTs (standard care) for discharge $(\mathrm{RR}=1.08,95 \% \mathrm{CI}=1.00-1.18, P=0.06 ; \mathrm{RR}=1.14$, $95 \% \mathrm{CI}=1.07-1.21, P<0.0001 ; \mathrm{RR}=1.10,95 \% \mathrm{CI}=$ $0.93-1.29, P=0.27 ; \mathrm{RR}=1.10,95 \% \mathrm{CI}=1.03-1.18$, $P=0.008$ ) (Figure 1B and Supplementary Figure 3).

We unobserved a significant association between tocilizumab and a decreased risk of secondary infections in the overall analysis $(\mathrm{RR}=1.05,95 \% \mathrm{CI}=$ $0.89-1.24)$. However, there was a slight between-trial heterogeneity $\left(I^{2}=48 \% ; P=0.08\right)$. We did not discover significant associations between tocilizumab treatment and secondary infection risk in peer-reviewed, preprint RCTs, double-blind (placebo plus standard care), and open-label RCTs (standard care) subgroups. We also failed to find significant associations between tocilizumab and patients of adverse events as well as patients of serious adverse events (Figure 1C and Supplementary Figures 4, 5).

\section{Risk of bias}

The risk of bias for all-cause mortality, in-patient discharge rate, number of patients experiencing serious adverse events and adverse events, number of patients' intubation or death, and number of secondary infections were thought low for 8 of the 10 RCTs. The other two RCTs have some concerns (NCT04346355), and 1 RCT was considered high (NCT04381936) (Figure 2). 
Table 1. Characteristics of the 8 RCTs in the meta-analysis.

\begin{tabular}{|c|c|c|c|c|c|c|c|c|c|c|c|}
\hline Author & & $\begin{array}{c}\text { Olivier } \\
\text { Hermine }\end{array}$ & $\begin{array}{c}\text { Carlo } \\
\text { Salvarani }\end{array}$ & J.H. Stone & $\begin{array}{c}\text { Carlos } \\
\text { Salama }\end{array}$ & I.O. Rosas & $\begin{array}{c}\text { Viviane C } \\
\text { Veiga }\end{array}$ & Suresh Kumar & $\begin{array}{c}\text { Arvinder } \\
\text { S Soin }\end{array}$ & $\begin{array}{c}\text { Anthony C. } \\
\text { Gordon }\end{array}$ & $\begin{array}{c}\text { Peter W } \\
\text { Horby }\end{array}$ \\
\hline $\begin{array}{l}\text { Trial } \\
\text { registration }\end{array}$ & & $\begin{array}{c}\text { NCT } \\
04331808\end{array}$ & $\begin{array}{c}\text { NCT } \\
04346355\end{array}$ & $\begin{array}{c}\text { NCT } \\
04356937\end{array}$ & $\begin{array}{c}\text { NCT } \\
04372186\end{array}$ & $\begin{array}{c}\text { NCT } \\
04320615\end{array}$ & $\begin{array}{c}\text { NCT } \\
04403685\end{array}$ & $\begin{array}{c}\text { CTRI/2020/05/ } \\
024959\end{array}$ & $\begin{array}{c}\text { CTRI/ } \\
2020 / 05 / 0 \\
25369\end{array}$ & $\begin{array}{c}\text { NCT } \\
02735707\end{array}$ & $\begin{array}{c}\text { NCT } \\
04381936\end{array}$ \\
\hline Time & & 20201020 & 20201020 & 20201021 & 20201217 & 20210225 & 20210120 & 20201201 & 20210504 & 20210422 & 20210211 \\
\hline Country & & France & Italy & USA & USA & USA & Brazil & India & India & International & UK \\
\hline Race & & Caucasian & Caucasian & Mix & Mix & Mix & Mix & Asian & Caucasian & Mix & Mix \\
\hline $\begin{array}{l}\text { Disease } \\
\text { severity }\end{array}$ & & $\begin{array}{l}\text { Moderate } \\
\text { or severe }\end{array}$ & NA & Severe & NA & Severe & $\begin{array}{l}\text { Severe or } \\
\text { critical }\end{array}$ & $\begin{array}{c}\text { Moderate or } \\
\text { severe }\end{array}$ & $\begin{array}{l}\text { Moderate } \\
\text { or severe }\end{array}$ & Critical & Severe \\
\hline $\begin{array}{l}\text { Dose } \\
\text { description }\end{array}$ & & $\begin{array}{c}8 \mathrm{mg} / \mathrm{kg} \\
\text { maximum } \\
800 \mathrm{mg}\end{array}$ & $\begin{array}{c}8 \mathrm{mg} / \mathrm{kg} \\
\text { maximum } \\
800 \mathrm{mg}\end{array}$ & $\begin{array}{c}8 \mathrm{mg} / \mathrm{kg} \\
\text { maximum } \\
800 \mathrm{mg}\end{array}$ & $\begin{array}{c}8 \mathrm{mg} / \mathrm{kg} \\
\text { maximum } \\
800 \mathrm{mg}\end{array}$ & $\begin{array}{c}8 \mathrm{mg} / \mathrm{kg} \\
\text { maximum } \\
800 \mathrm{mg}\end{array}$ & $\begin{array}{c}8 \mathrm{mg} / \mathrm{kg} \\
\text { maximum } \\
800 \mathrm{mg}\end{array}$ & $\begin{array}{c}1.6 \mathrm{mg} / \mathrm{kg} \\
\text { and continued } \\
\text { with } 0.8 \mathrm{mg} / \mathrm{kg} \\
\text { dose weekly } \\
\text { regimen }\end{array}$ & $\begin{array}{c}6 \mathrm{mg} / \mathrm{kg} \\
\text { maximum } \\
800 \mathrm{mg}\end{array}$ & $\begin{array}{c}8 \mathrm{mg} / \mathrm{kg} \\
\text { maximum } \\
800 \mathrm{mg}\end{array}$ & $\begin{array}{l}400 \mathrm{mg}- \\
800 \mathrm{mg}\end{array}$ \\
\hline $\begin{array}{l}\text { Type of } \\
\text { control }\end{array}$ & & Usual care & $\begin{array}{l}\text { Standard } \\
\text { care }\end{array}$ & $\begin{array}{l}\text { Placebo } \\
\text { plus } \\
\text { standard } \\
\text { care }\end{array}$ & $\begin{array}{l}\text { Placebo } \\
\text { plus } \\
\text { standard } \\
\text { care }\end{array}$ & $\begin{array}{l}\text { Placebo } \\
\text { plus } \\
\text { standard } \\
\text { care }\end{array}$ & $\begin{array}{l}\text { Standard } \\
\text { care }\end{array}$ & $\begin{array}{c}\text { Best supportive } \\
\text { care }\end{array}$ & $\begin{array}{l}\text { Standard } \\
\text { care }\end{array}$ & $\begin{array}{l}\text { Standard } \\
\text { care }\end{array}$ & $\begin{array}{l}\text { Standard } \\
\text { care }\end{array}$ \\
\hline Study type & & $\begin{array}{c}\text { Open-label } \\
\text { RCT }\end{array}$ & $\begin{array}{c}\text { Open-label } \\
\text { RCT }\end{array}$ & $\begin{array}{c}\text { Double- } \\
\text { blind RCT }\end{array}$ & $\begin{array}{c}\text { Double- } \\
\text { blind RCT }\end{array}$ & $\begin{array}{c}\text { Double- } \\
\text { blind RCT }\end{array}$ & $\begin{array}{c}\text { Open-label } \\
\text { RCT }\end{array}$ & $\begin{array}{c}\text { Open-label } \\
\text { RCT }\end{array}$ & $\begin{array}{c}\text { Open- } \\
\text { label RCT }\end{array}$ & $\begin{array}{c}\text { Open-label } \\
\text { RCT }\end{array}$ & $\begin{array}{c}\text { Open-label } \\
\text { RCT }\end{array}$ \\
\hline Peer-reviewed & & Yes & Yes & Yes & Yes & Yes & Yes & Yes & Yes & Yes & No \\
\hline $\begin{array}{l}\text { Publication } \\
\text { format }\end{array}$ & & Publish & Publish & Publish & Publish & Publish & Publish & Publish & Publish & Publish & Preprint \\
\hline $\begin{array}{l}\text { No. planned } \\
\text { of inclusion }\end{array}$ & & 131 & 126 & 1560 & 445 & 479 & 129 & 36 & 183 & 2046 & 21550 \\
\hline No. included & & 130 & 123 & 243 & 377 & 438 & 129 & 30 & 180 & 865 & 4116 \\
\hline Tocilizumab & & 63 & 60 & 161 & 249 & 294 & 65 & 20 & 91 & 353 & 2022 \\
\hline Control & & 67 & 63 & 82 & 128 & 144 & 64 & 10 & 88 & 402 & 2094 \\
\hline \multirow{2}{*}{ Mortality } & Tocilizumab & $28 \mathrm{~d}: 7$ & $30 \mathrm{~d}: 2$ & 28d: 9 & $28 \mathrm{~d}: 26$ & $28 \mathrm{~d}: 58$ & $28 \mathrm{~d}: 14$ & 30d:0 & 28d:11 & 30d:87 & $28 \mathrm{~d}: 596$ \\
\hline & Control & $28 \mathrm{~d}: 8$ & 30d:1 & $28 \mathrm{~d}: 3$ & 28d:11 & $28 \mathrm{~d}: 28$ & $28 \mathrm{~d}: 6$ & 30d:3 & 28d:15 & 30d:134 & 28d:694 \\
\hline \multirow{2}{*}{ Discharge } & Tocilizumab & $28 \mathrm{~d}: 52$ & 30d:54 & $28 \mathrm{~d}: 147$ & & $28 \mathrm{~d}: 180$ & $28 \mathrm{~d}: 35$ & 30d:16 & & 30d:190 & 28d:1093 \\
\hline & Control & 28d:49 & 30d:58 & $28 \mathrm{~d}: 72$ & & $28 \mathrm{~d}: 74$ & $28 \mathrm{~d}: 31$ & 30d:6 & & 30d:184 & 28d:999 \\
\hline \multirow{2}{*}{$\begin{array}{l}\text { Patients of } \\
\text { adverse events }\end{array}$} & Tocilizumab & $28 \mathrm{~d}: 28$ & & & $60 \mathrm{~d}: 127$ & $28 \mathrm{~d}: 228$ & $28 \mathrm{~d}: 29$ & 30d:18 & $28 \mathrm{~d}: 30$ & & \\
\hline & Control & $28 \mathrm{~d}: 36$ & & & 60d:67 & $28 \mathrm{~d}: 116$ & $28 \mathrm{~d}: 21$ & 30d:4 & $28 \mathrm{~d}: 22$ & & \\
\hline \multirow{2}{*}{$\begin{array}{l}\text { Patients of } \\
\text { serious } \\
\text { adverse events }\end{array}$} & Tocilizumab & $28 \mathrm{~d}: 20$ & & $28 \mathrm{~d}: 28$ & & $28 \mathrm{~d}: 103$ & 28d:11 & & $28 \mathrm{~d}: 15$ & 30d:9 & \\
\hline & Control & $28 \mathrm{~d}: 29$ & & $28 \mathrm{~d}: 12$ & & $28 \mathrm{~d}: 55$ & $28 \mathrm{~d}: 7$ & & $28 \mathrm{~d}: 15$ & 30d:11 & \\
\hline \multirow{2}{*}{$\begin{array}{l}\text { Secondary } \\
\text { infection }\end{array}$} & Tocilizumab & $28 \mathrm{~d}: 2$ & 30d:1 & $28 \mathrm{~d}: 13$ & $60 \mathrm{~d}: 25$ & $28 \mathrm{~d}: 113$ & $28 \mathrm{~d}: 10$ & 30d:1 & $28 \mathrm{~d}: 5$ & 30d:1 & \\
\hline & Control & $28 \mathrm{~d}: 14$ & 30d:4 & $28 \mathrm{~d}: 14$ & $60 \mathrm{~d}: 16$ & $28 \mathrm{~d}: 58$ & $28 \mathrm{~d}: 10$ & $30 \mathrm{~d}: 3$ & $28 \mathrm{~d}: 5$ & 30d:0 & \\
\hline \multirow{2}{*}{$\begin{array}{l}\text { Incubation or } \\
\text { death }\end{array}$} & Tocilizumab & 15 & & 17 & & & & & & & $571(1754)$ \\
\hline & Control & 24 & & 10 & & & & & & & $687(1800)$ \\
\hline
\end{tabular}

The mix of Severity, Symptoms of the disease include moderate, severe, and critical; Mix of Race, including Asian, Caucasian, African, and so on; RCT, Randomized controlled trial; NA, no appearance.

\section{DISCUSSION}

9 RCTs were published in peer-reviewed journals in the meta-analysis. We revealed that tocilizumab treatment was not significantly associated with reducing all-cause mortality among COVID-19 patients compared with placebo plus standard of care or standard of care alone. However, combined with additional 1 RCTs published in preprint journals, we observed that tocilizumab treatment significantly reduced all-cause mortality in COVID-19 patients. The risk of bias in the
RECOVERY trial (NCT04381936) is very high, and the combined results of the RECOVERY trial are not very reliable. Evidence that tocilizumab reduces all-cause mortality in COVID-19 patients requires further proof.

In the overall analysis, we discovered a significant increase in hospital discharge rates after patients with COVID-19 pneumonia received tocilizumab. We observed similar results for the peer-reviewed, preprint RCTs, double-blind (placebo plus standard care), and open-label RCTs (standard care) for discharge. We 


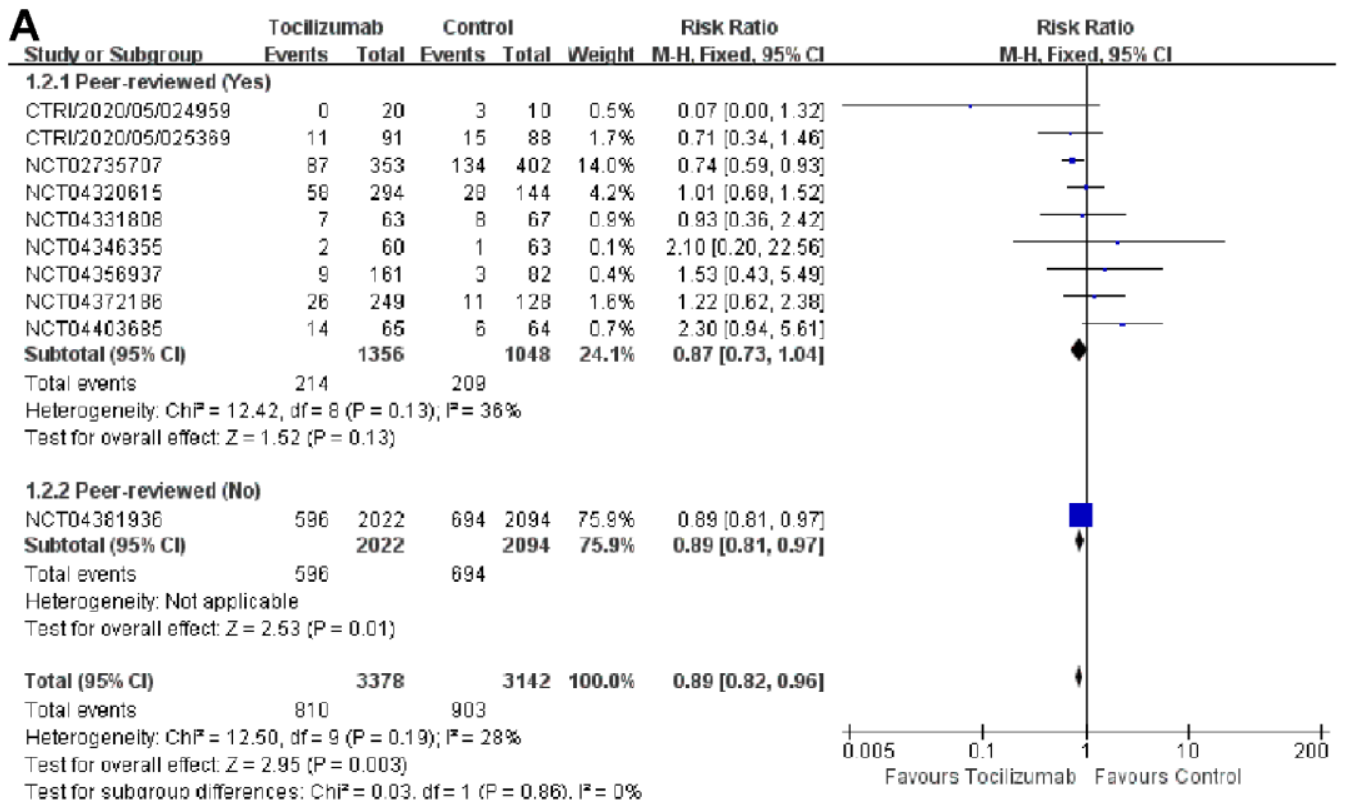

B Tocilizumab Control Risk Ratio

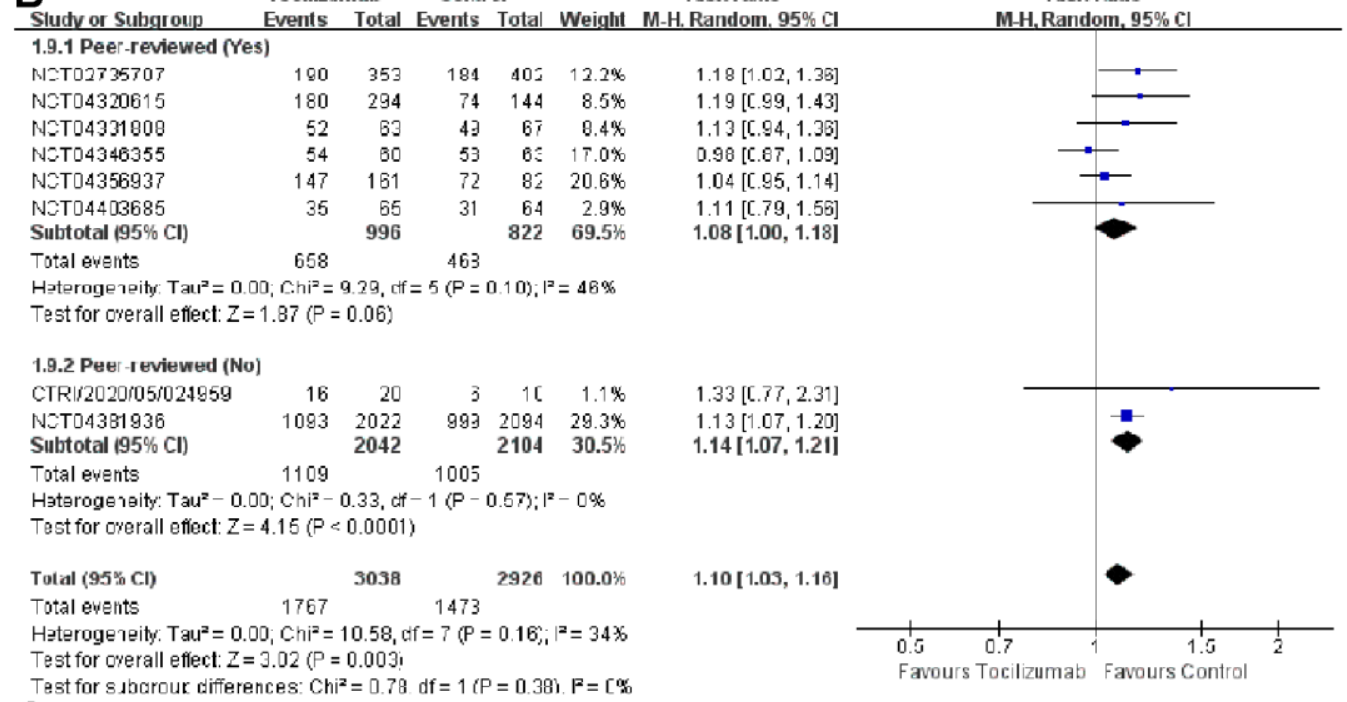

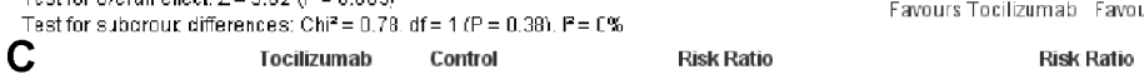

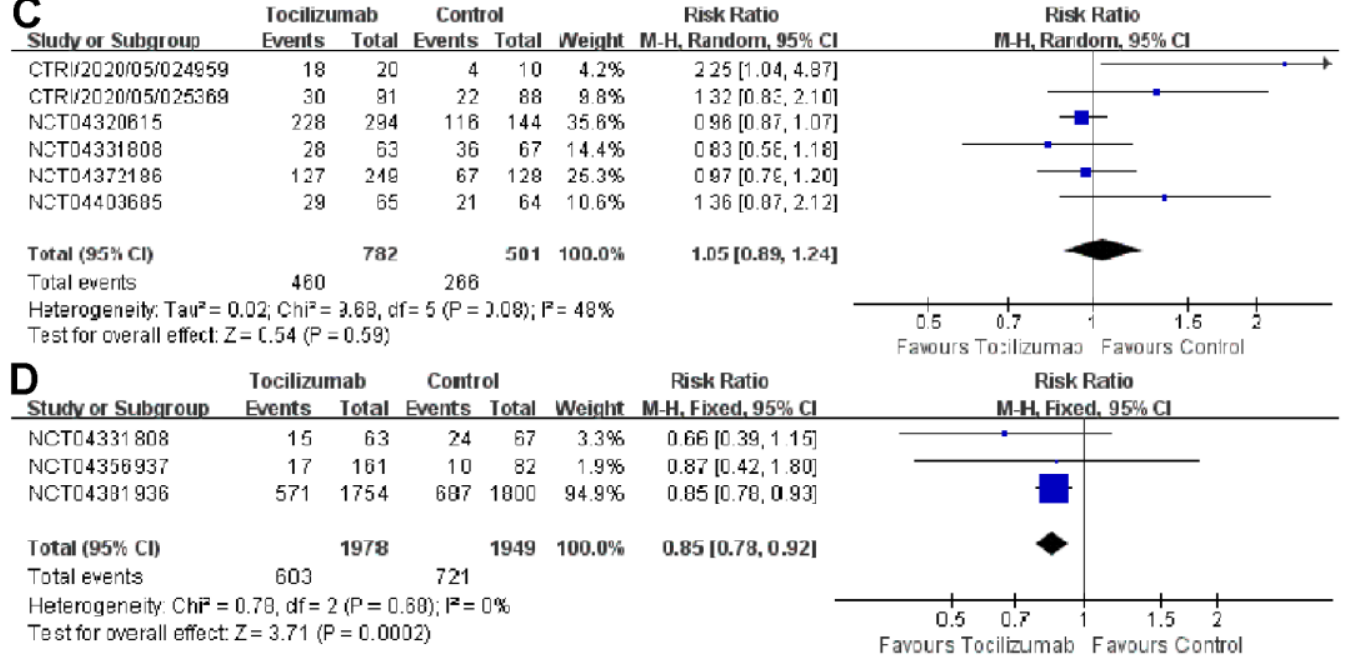

Figure 1. Association of tocilizumab with all-cause mortality, discharge, patients of adverse events, and date of incubation or death in the published study and preprint study (A) all-cause mortality (B) discharge (C) patients of adverse events (D) date of incubation or death. 
notably also found that tocilizumab significantly reduced the rate of intubation or death in COVID-19 patients in 3 RCTs.

Tocilizumab was not significantly associated with harm on other patient-relevant clinical outcomes, including increasing secondary infection risk, patients of adverse events, or patients of serious adverse events. The possible reason is tocilizumab treatment significantly increased COVID-19 discharge rates in patients with mild disease compared to standard care alone or placebo. In severe or critically ill patients, because mortality is a multifactorial outcome. In critically ill patients, medical personnel use all available medical means to save patients' lives; we did not find that tocilizumab significantly reduced all-cause mortality.

We found our evidence was dominated mainly by the RECOVERY trial (NCT04381936), which amounted to $76 \%$ of the meta-analysis weight [21]. After eliminating the RECOVERY trial, we failed to find a significant association between tocilizumab and all-cause mortality, intubation, or mortality in patients with COVID-19 [21]. However, excluding the RECOVERY trial, we found that tocilizumab effectively increased patients' discharge rate with COVID-19.

Carlo Salvarani et al. [7] was prematurely interrupted the trial after an interim analysis for futility. Three randomized, double-blind, placebo-controlled trials reported tocilizumab treatment did not significantly result in better clinical status or lower mortality than placebo at point time [5, 6, 8]. Three open-label published RCTs also said tocilizumab treatment plus standard care was not slightly superior to usual care alone in improving clinical outcomes $[4,7,9]$.

Viviane C Veiga et al. [9] reported that two patients in the standard care group received tocilizumab treatment. Peter W Horby et al. [21] also said that forty-four participants (3\%) assigned to usual care received at least one dose of tocilizumab in the RECOVERY trial. Timotius Ivan Hariyanto et al. [22] also observed that tocilizumab is effective in reducing the biomarkers of the COVID-19 infection. Overall, we believe that tocilizumab significantly increased the discharge rate of patients with COVID-19 but did not decrease all-cause mortality and increase the risk of secondary infection, patients with adverse events, or patients with serious adverse events in the meta-analysis. Therefore, we recommend that clinicians be cautious in using tocilizumab in patients with COVID-19pneumonia.

We have to consider several limitations in our study. Firstly, in the absence of every patient's clinical test data, patients with high clinical indicators (such as IL-6, C-reactive protein, and so on) will benefit most when tocilizumab treatment. Secondly, two of the 10 RCTs

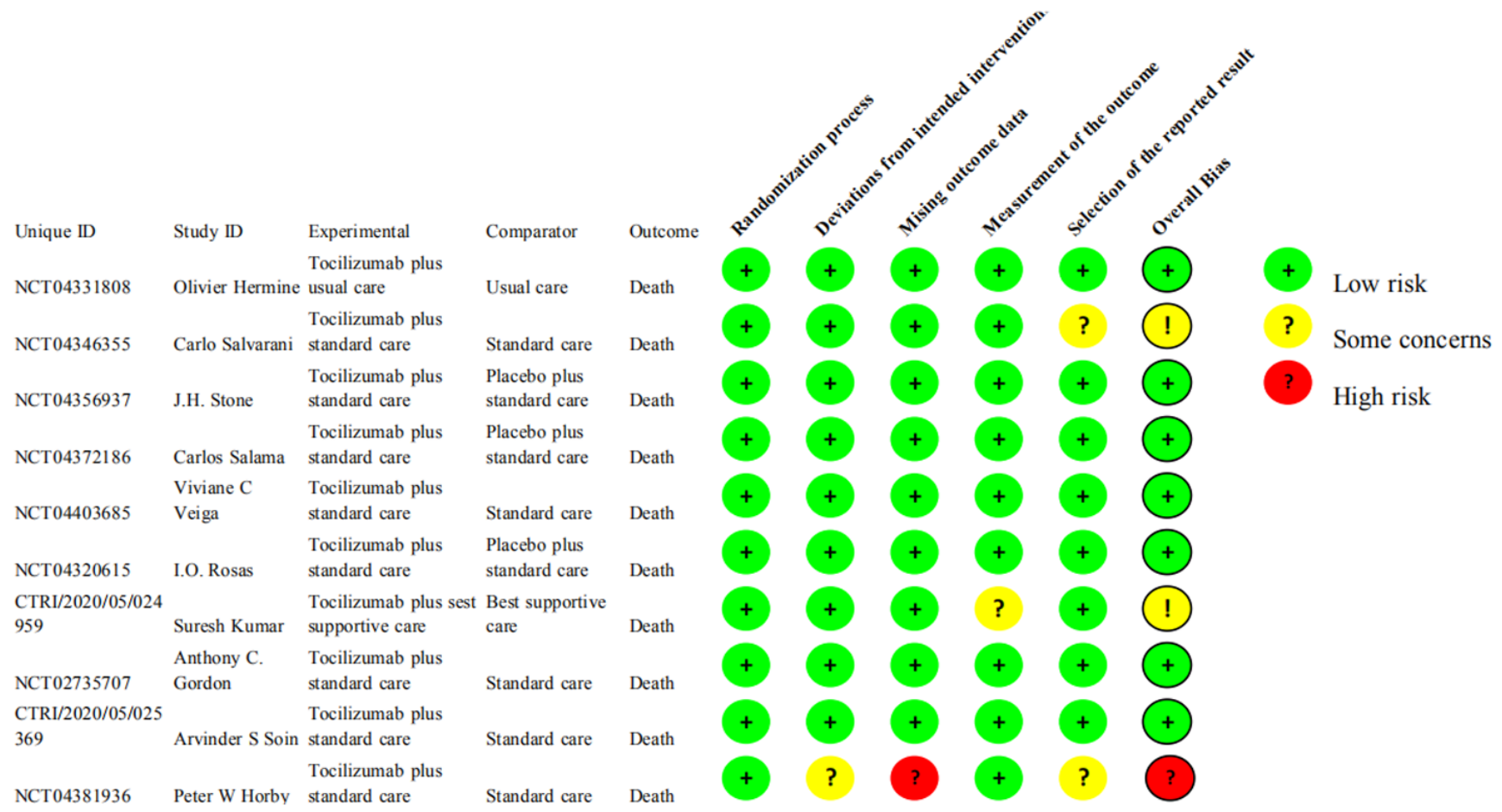

Figure 2. Risk of bias assessments for the outcomes of all RCTs. 
had some concerns, and one RCT have an increased risk of bias. The RECOVERY trial (NCT04381936) accounted for $76 \%$ of the weight in our meta-analysis. Thirdly, two RCTs reported that some patients in the standard care group also received tocilizumab, which may affect the efficacy evaluation [1, 23-25].

\section{CONCLUSIONS}

Tocilizumab significantly increased the discharge rate of patients with COVID-19. Still, it did not decrease allcause mortality and increased the risk of secondary infection, patients of adverse events, or patients of serious adverse events.

\section{MATERIALS AND METHODS}

We conducted the systematic review and meta-analysis of 10 RCTs examining the association between tocilizumab treatment and clinical outcomes in COVID-19 patients (Figure 3). We recorded the metaanalysis under the Preferred Reporting Items for Systematic Reviews and Meta-Analyses (PRISMA) guidelines.

\section{PRISMA 2020 flow diagram for new systematic reviews which included searches of databases and registers only}

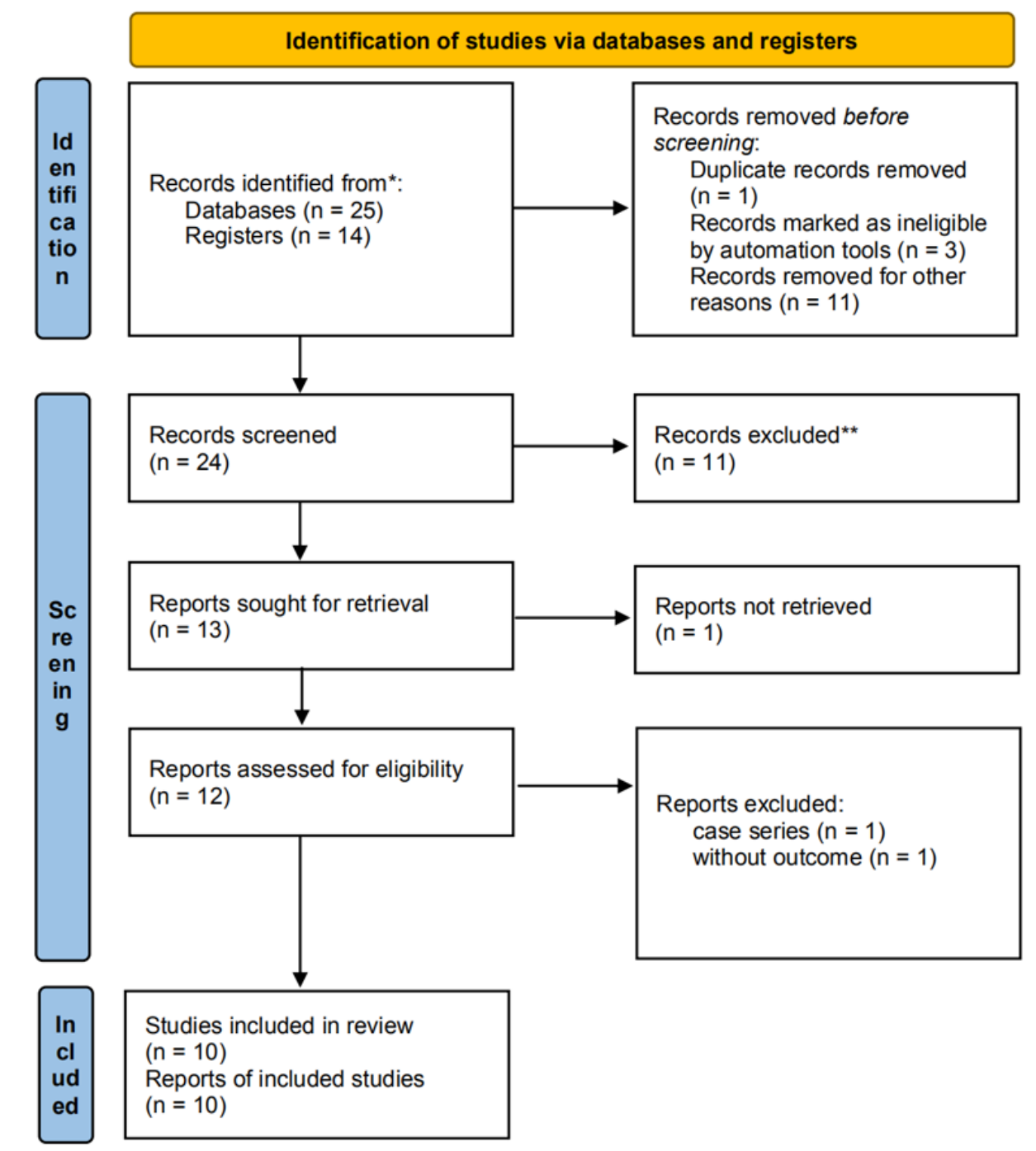

*Consider, if feasible to do so, reporting the number of records identified from each database or register searched (rather than the total number across all databases/registers).

**If automation tools were used, indicate how many records were excluded by a human and how many were excluded by automation tools.

Figure 3. Flow diagram of the study selection process. 


\section{Search strategy}

Three review authors (Jingwen Peng, Weida Liu, and Huan Mei) systematically searched PubMed and MedRxiv for all RCTs as of June 1, 2021, to assess the benefits or harms of tocilizumab to treat patients with COVID-19 pneumonia (Figure 3). We additionally reviewed the references for included articles and previous systematic reviews. We compared included items and resolved disagreements.

\section{RCTs selection}

The selected RCTs included participants with suspected or confirmed SARS-CoV-2 infection randomly assigned to receive tocilizumab, only standard of care or best supportive care, or a placebo together with the standard of care. We included all RCTs regardless of the tocilizumab dose (i.e., $400 \mathrm{mg}-800 \mathrm{mg}, 1.6 \mathrm{mg} / \mathrm{kg}$ and weekly continued with $0.8 \mathrm{mg} / \mathrm{kg}$ dose regimen or 8 $\mathrm{mg} / \mathrm{kg}$ maximum $800 \mathrm{mg}$ ) or health care setting. We excluded retrospective studies, case reports, and the RCTs designed to prevent the occurrence of COVID-19.

\section{Data extraction}

We carefully extracted the relevant information for all RCTs: baseline characteristics of the patients, trial design characteristics (Trial registration, blinding, and randomization procedure), description of the experimental and control groups, tocilizumab dose, and trial location. Data on outcomes (Jingwen Peng and Huan Mei) and features (Jingwen Peng and Weida Liu) were extracted independently by two reviewers.

\section{Outcomes}

The outcomes were:

1. All-cause mortality 28 days or 30 days.

2. In-patient discharge rate.

3. The number of patients experiencing serious adverse events and adverse events.

4. The number of secondary infections.

5. The number of patients' intubation or death.

\section{Risk of bias assessment}

Two investigators (Jingwen Peng and Weida Liu) independently assessed the risk of bias for clinical outcomes in all trials using the internationally recognized tool (Revised Cochrane risk of bias tool for randomized trials, RoB 2.0). All authors accounted for any discrepancies in the investigator's quality assessment and discussed until everyone reached a consensus.

\section{Statistical analyses}

We performed the meta-analysis to assess the treatment effects using risk ratio (RR) and corresponding $95 \%$ confidence intervals (CI). We analyzed outcomes with available data (all-cause mortality, in-patient discharge rate, number of patients experiencing serious adverse events and adverse events, number of secondary infections, and patient intubation or death). We use DerSimonian and Laird methods to pool data from the meta-analysis with the random-effects model and the fixed-effects model of the Mantel-Haenszel method. We used Begg/Egger test and visually on a funnel plot to assess the metaanalysis and examine publication bias. We have not summarized treatment effects for clinical improvement or deterioration, length of hospital stay, and the number of mechanical ventilation due to inconsistent definitions of these outcomes and insufficient reporting of pertinent details. All analyses were carried out using RevMan version 5.4.1.

\section{Data availability}

The datasets generated during and analyzed during the current study are available from the corresponding author on reasonable request.

\section{AUTHOR CONTRIBUTIONS}

JWP, XDS, and WDL conceived and designed the experiments. JWP, WDL, and HM performed publication searches and selection. JWP, QW, and HLZ analyzed the data. JWP, GZL, and XDS prepared the figures. JWP and MHF contributed materials/analysis tools. JWP and WDL wrote and revised the paper. All authors reviewed and considered the manuscript.

\section{ACKNOWLEDGMENTS}

We additionally appreciate the valuable comments from other members of our laboratory.

\section{CONFLICTS OF INTEREST}

The authors declare that they have no conflicts of interest.

\section{FUNDING}

The work was supported financially by the subitem of the Important and Special Project of the Science and Technology Ministry of China (No. 2018ZX10734404), the National Natural Science Foundation of China (No.81972949), the National Science and Technology Infrastructure of China (No. 
NPRC-32), Nanjing Incubation Program for National Clinical Research Center (No.2019060001), and National Mega-project for Innovative Drugs (No. 2019ZX09721001).

\section{REFERENCES}

1. Jiang $W$, Li W, Xiong L, Wu Q, Wu J, He B, Shen J, Pang R, Luo T, Guo Y, Yang Y, Han Y, Dai W, et al. Clinical efficacy of convalescent plasma therapy on treating COVID-19 patients: Evidence from matched study and a meta-analysis. Clin Transl Med. 2020; 10:e259. https://doi.org/10.1002/ctm2.259 PMID:33377664

2. Jamilloux $Y$, Henry $T$, Belot $A$, Viel $S$, Fauter $M$, El Jammal T, Walzer T, François $B$, Sève $P$. Should we stimulate or suppress immune responses in COVID-19? Cytokine and anti-cytokine interventions. Autoimmun Rev. 2020; 19:102567. https://doi.org/10.1016/i.autrev.2020.102567 PMID:32376392

3. Peng J, Wang $Q$, Mei $H$, Zheng $H$, Liang $G$, She X, Liu W. Fungal co-infection in COVID-19 patients: evidence from a systematic review and meta-analysis. Aging (Albany NY). 2021; 13:7745-57. https://doi.org/10.18632/aging.202742 PMID:33744863

4. Hermine $\mathrm{O}$, Mariette $\mathrm{X}$, Tharaux $\mathrm{PL}$, Resche-Rigon $\mathrm{M}$, Porcher R, Ravaud P, Bureau S, Dougados M, Tibi A, Azoulay E, Cadranel J, Emmerich J, Fartoukh M, and CORIMUNO-19 Collaborative Group. Effect of Tocilizumab vs Usual Care in Adults Hospitalized With COVID-19 and Moderate or Severe Pneumonia: A Randomized Clinical Trial. JAMA Intern Med. 2021; 181:32-40.

https://doi.org/10.1001/jamainternmed.2020.6820 PMID:33080017

5. Rosas IO, Bräu N, Waters M, Go RC, Hunter BD, Bhagani S, Skiest D, Aziz MS, Cooper N, Douglas IS, Savic S, Youngstein T, Del Sorbo L, et al. Tocilizumab in Hospitalized Patients with Severe Covid-19 Pneumonia. N Engl J Med. 2021; 384:1503-16. https://doi.org/10.1056/NEJMoa2028700 PMID:33631066

6. Salama C, Han J, Yau L, Reiss WG, Kramer B, Neidhart JD, Criner GJ, Kaplan-Lewis E, Baden R, Pandit L, Cameron ML, Garcia-Diaz J, Chávez V, et al. Tocilizumab in Patients Hospitalized with Covid-19 Pneumonia. N Engl J Med. 2021; 384:20-30. https://doi.org/10.1056/NEJMoa2030340 PMID:33332779

7. Salvarani C, Dolci G, Massari M, Merlo DF, Cavuto S, Savoldi L, Bruzzi P, Boni F, Braglia L, Turrà C, Ballerini PF, Sciascia R, Zammarchi L, et al, and RCT-TCZ-COVID-
19 Study Group. Effect of Tocilizumab vs Standard Care on Clinical Worsening in Patients Hospitalized With COVID-19 Pneumonia: A Randomized Clinical Trial. JAMA Intern Med. 2021; 181:24-31. https://doi.org/10.1001/jamainternmed.2020.6615 PMID: $\underline{3080005}$

8. Stone JH, Frigault MJ, Serling-Boyd NJ, Fernandes $A D$, Harvey L, Foulkes AS, Horick NK, Healy BC, Shah R, Bensaci AM, Woolley AE, Nikiforow $\mathrm{S}$, Lin N, et al, and BACC Bay Tocilizumab Trial Investigators. Efficacy of Tocilizumab in Patients Hospitalized with Covid-19. N Engl J Med. 2020; 383:2333-44.

https://doi.org/10.1056/NEJMoa2028836 PMID: $\underline{3085857}$

9. Veiga VC, Prats JA, Farias DL, Rosa RG, Dourado LK, Zampieri FG, Machado FR, Lopes RD, Berwanger O, Azevedo LC, Avezum Á, Lisboa TC, Rojas SS, et al, and Coalition covid-19 Brazil VI Investigators. Effect of tocilizumab on clinical outcomes at 15 days in patients with severe or critical coronavirus disease 2019: randomised controlled trial. BMJ. 2021; 372:n84.

https://doi.org/10.1136/bmj.n84 PMID: $\underline{3472855}$

10. Guaraldi G, Meschiari M, Cozzi-Lepri A, Milic J, Tonelli $R$, Menozzi M, Franceschini E, Cuomo G, Orlando G, Borghi V, Santoro A, Di Gaetano M, Puzzolante C, et al. Tocilizumab in patients with severe COVID-19: a retrospective cohort study. Lancet Rheumatol. 2020; 2:e474-84. https://doi.org/10.1016/S2665-9913(20)30173-9 PMID:32835257

11. Kewan T, Covut F, Al-Jaghbeer MJ, Rose L, Gopalakrishna KV, Akbik B. Tocilizumab for treatment of patients with severe COVID-19: A retrospective cohort study. EClinicalMedicine. 2020; 24:100418.

https://doi.org/10.1016/i.eclinm.2020.100418 PMID:32766537

12. Schett G, Manger B, Simon D, Caporali R. COVID-19 revisiting inflammatory pathways of arthritis. Nat Rev Rheumatol. 2020; 16:465-70. https://doi.org/10.1038/s41584-020-0451-z PMID:32561873

13. Kimmig LM, Wu D, Gold M, Pettit NN, Pitrak D, Mueller J, Husain AN, Mutlu EA, Mutlu GM. IL-6 Inhibition in Critically III COVID-19 Patients Is Associated With Increased Secondary Infections. Front Med (Lausanne). 2020; 7:583897.

https://doi.org/10.3389/fmed.2020.583897 PMID:33195334

14. Tian J, Zhang $M$, Jin $M$, Zhang $F$, Chu $Q$, Wang $X$, Chen C, Yue $H$, Zhang L, Du R, Zhao D, Zeng Z, Zhao Y, et al. Repurposed Tocilizumab in Patients with Severe COVID-19. J Immunol. 2021; 206:599-606. 
https://doi.org/10.4049/jimmunol.2000981 PMID:33298617

15. Potere N, Di Nisio M, Cibelli D, Scurti R, Frattari A, Porreca E, Abbate A, Parruti G. Interleukin-6 receptor blockade with subcutaneous tocilizumab in severe COVID-19 pneumonia and hyperinflammation: a casecontrol study. Ann Rheum Dis. 2021; 80:1-2. https://doi.org/10.1136/annrheumdis-2020-218243 PMID:32647027

16. Rodríguez-Baño J, Pachón J, Carratalà J, Ryan $P$, Jarrín I, Yllescas M, Arribas JR, Berenguer J, Aznar Muñoz E, Gil Divasson P, González Muñiz P, Muñoz Aguirre C, Díaz Menéndez $M$, et al, and SAM-COVID Study Group, and Fundación SEIMC-GESIDA, and Hospital Universitario La Paz, and Hospital Universitario Gregorio Marañón, and Hospital Infanta Leonor, and Complejo Hospitalario Virgen de la Salud, and Hospital Universitario Rafael Méndez, and Hospital Universitario de Cruces, and Hospital de Melilla, and Hospital San Eloy de Barakaldo, and Hospital Universitario Central de Asturias, and Hospital Universitario Puerto Real, and Hospital do Salnés, and Hospital del Mar, and Hospital Virgen de la Arrixaca, and Hospital Clínico San Cecilio, and Parc Sanitari Sant Joan de Déu, and Hospital Josep Trueta, and Hospital Dos De Maig - Consorci Sanitari Integral, and Hospital Clínico Universitario de Valencia, and Complejo Asistencial de Ávila, and Hospital Universitario Marqués de Valdecilla, and Hospital de Barcelona SCIAS, and Hospital Álvaro Cunqueiro, and Hospital Universitario Severo Ochoa, and Hospital CIMASanitas, and Hospital La Inmaculada, and Hospital de Guadalajara, and Hospital Universitario Infanta Sofia, and Hospital Comarcal de Blanes, and Hospital Universitario de Gran Canaria Dr Negrín, and Hospital Son Espases, and Complejo Hospitalario Universitario A Coruña, and Hospital Costa del Sol, and Hospital Clínico Universitario Lozano Blesa, and Hospital Mutua de Terrassa, and Hospital Universitario Virgen Macarena, and Hospital Universitari de Bellvitge, and Hospital Universitario y Politécnico La Fe, and Hospital de Sabadell (Parc Tauli), and Hospital Fundación Jiménez Díaz, and Hospital Clínico Universitario de Valladolid, and Hospital Son Llatzer, and Hospital Universitario de Álava, and Complejo Hospitalario Universitario Santa Lucía, and Hospital General Universitario Reina Sofía, and Complejo Hospitalario Universitario de Ferrol, and Hospital Universitario los Arcos del Mar Menor, and Hospital Universitario de Jerez, and Hospital de Donostia, and Hospital Juan Ramón Jiménez, and Hospital Vega Baja, and Hospital Puerta de Hierro, and Hospital Universitario de Getafe, and Hospital General de la Palma, and Fundación Hospital de Calahorra, and Hospital Alto Deba, and Hospital Universitario de
Jaén, and Hospital de Palamós, and Hospital Universitario de Valme, and Hospital Universitario Virgen del Rocío, and Hospital Universitario Ramón y Cajal, and Hospital Universitario San Pedro, and Hospital Regional de Málaga. Treatment with tocilizumab or corticosteroids for COVID-19 patients with hyperinflammatory state: a multicentre cohort study (SAM-COVID-19). Clin Microbiol Infect. 2021; 27:244-52.

https://doi.org/10.1016/i.cmi.2020.08.010 PMID:32860964

17. Ruiz-Antorán B, Sancho-López A, Torres F, MorenoTorres V, de Pablo-López I, García-López P, AbadSantos F, Rosso-Fernández CM, Aldea-Perona A, Montané E, Aparicio-Hernández RM, Llop-Rius R, Pedrós $\mathrm{C}$, et al, and TOCICOV-study group. Combination of Tocilizumab and Steroids to Improve Mortality in Patients with Severe COVID-19 Infection: A Spanish, Multicenter, Cohort Study. Infect Dis Ther. 2021; 10:347-62.

https://doi.org/10.1007/s40121-020-00373-8 PMID:33280066

18. Somers EC, Eschenauer GA, Troost JP, Golob JL, Gandhi TN, Wang L, Zhou N, Petty LA, Baang JH, Dillman NO, Frame D, Gregg KS, Kaul DR, et al. Tocilizumab for Treatment of Mechanically Ventilated Patients With COVID-19. Clin Infect Dis. 2021; 73:e445-54.

https://doi.org/10.1093/cid/ciaa954

PMID: $\underline{32651997}$

19. Soin AS, Kumar K, Choudhary NS, Sharma P, Mehta Y, Kataria S, Govil D, Deswal V, Chaudhry D, Singh PK, Gupta A, Agarwal V, Kumar S, et al. Tocilizumab plus standard care versus standard care in patients in India with moderate to severe COVID-19-associated cytokine release syndrome (COVINTOC): an open-label, multicentre, randomised, controlled, phase 3 trial. Lancet Respir Med. 2021; 9:511-21.

https://doi.org/10.1016/S2213-2600(21)00081-3 PMID:33676589

20. Gordon AC, Mouncey PR, Al-Beidh F, Rowan KM, Nichol AD, Arabi YM, Annane D, Beane A, van BentumPuijk W, Berry LR, Bhimani Z, Bonten MJ, Bradbury CA, et al, and REMAP-CAP Investigators. Interleukin-6 Receptor Antagonists in Critically III Patients with Covid-19. N Engl J Med. 2021; 384:1491-502. https://doi.org/10.1056/NEJMoa2100433 PMID:33631065

21. Recovery Collaborative Group. Tocilizumab in patients admitted to hospital with COVID-19 (RECOVERY): a randomised, controlled, open-label, platform trial. Lancet. 2021; 397:1637-45. https://doi.org/10.1016/S0140-6736(21)00676-0 PMID:33933206 
22. Ivan Hariyanto $T$, Kurniawan A. Tocilizumab administration is associated with the reduction in biomarkers of coronavirus disease 2019 infection. J Med Virol. 2021; 93:1832-6.

https://doi.org/10.1002/jmv.26698

PMID:33241872

23. Janiaud P, Axfors C, Schmitt AM, Gloy V, Ebrahimi F, Hepprich M, Smith ER, Haber NA, Khanna N, Moher D, Goodman SN, loannidis JP, Hemkens LG. Association of Convalescent Plasma Treatment With Clinical Outcomes in Patients With COVID-19: A Systematic Review and Meta-analysis. JAMA. 2021; 325:1185-95. https://doi.org/10.1001/jama.2021.2747 PMID:33635310
24. Kouzy R, Abi Jaoude J, Garcia Garcia CJ, El Alam MB, Taniguchi CM, Ludmir EB. Characteristics of the Multiplicity of Randomized Clinical Trials for Coronavirus Disease 2019 Launched During the Pandemic. JAMA Netw Open. 2020; 3:e2015100. https://doi.org/10.1001/jamanetworkopen.2020.15100 PMID:32658285

25. Lan SH, Lai CC, Huang HT, Chang SP, Lu LC, Hsueh PR. Tocilizumab for severe COVID-19: a systematic review and meta-analysis. Int J Antimicrob Agents. 2020; 56:106103.

https://doi.org/10.1016/j.ijantimicag.2020.106103 PMID:32712333 


\section{SUPPLEMENTARY MATERIALS}

\section{Supplementary Figures}

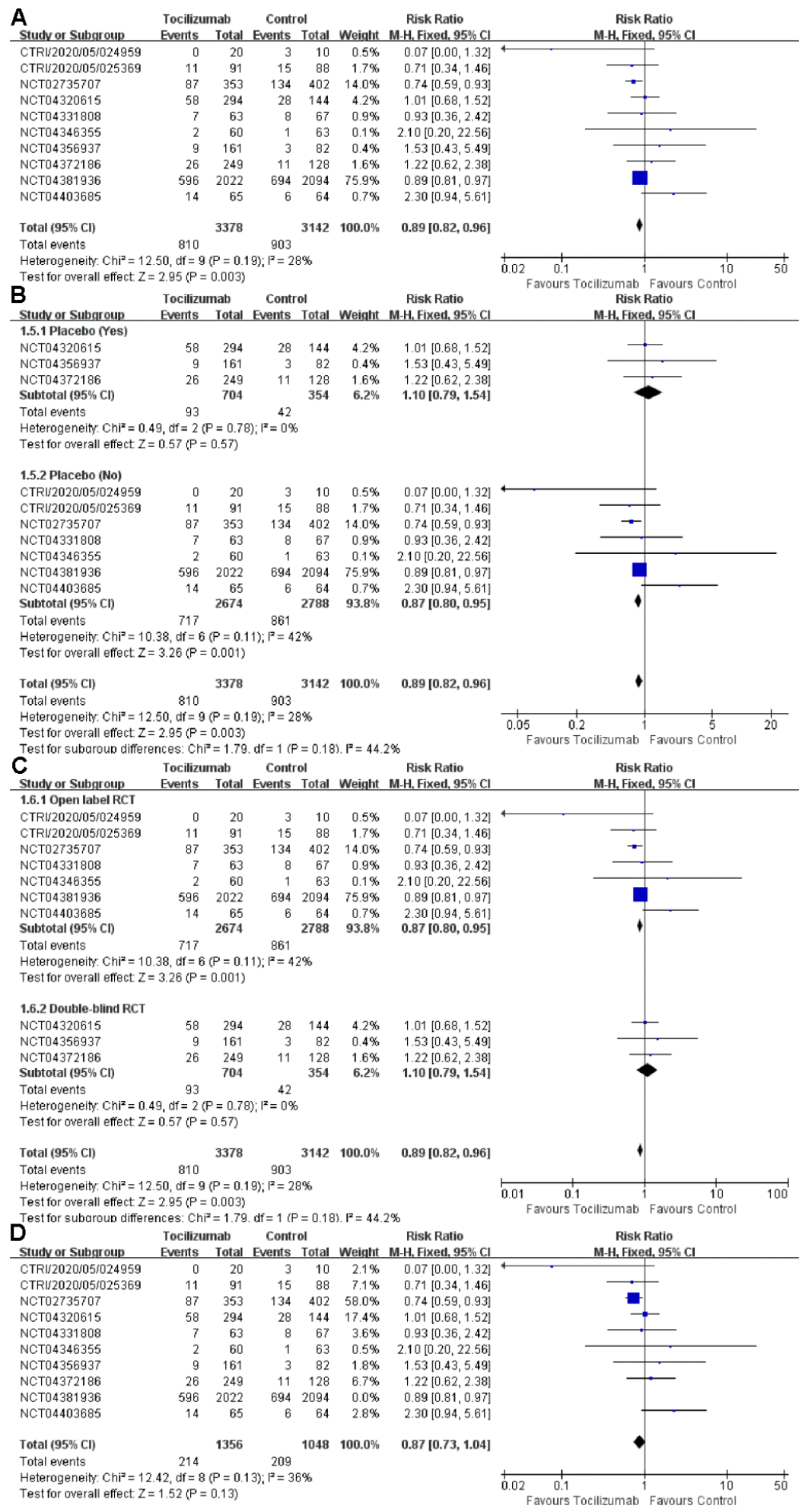

Supplementary Figure 1. Association of tocilizumab with all-cause mortality (A) all RCTs (B) study type (C) type of control (D) Forest plot without the RECOVERY trial. 
A Begg's funnel plot with pseudo $95 \%$ confidence limits

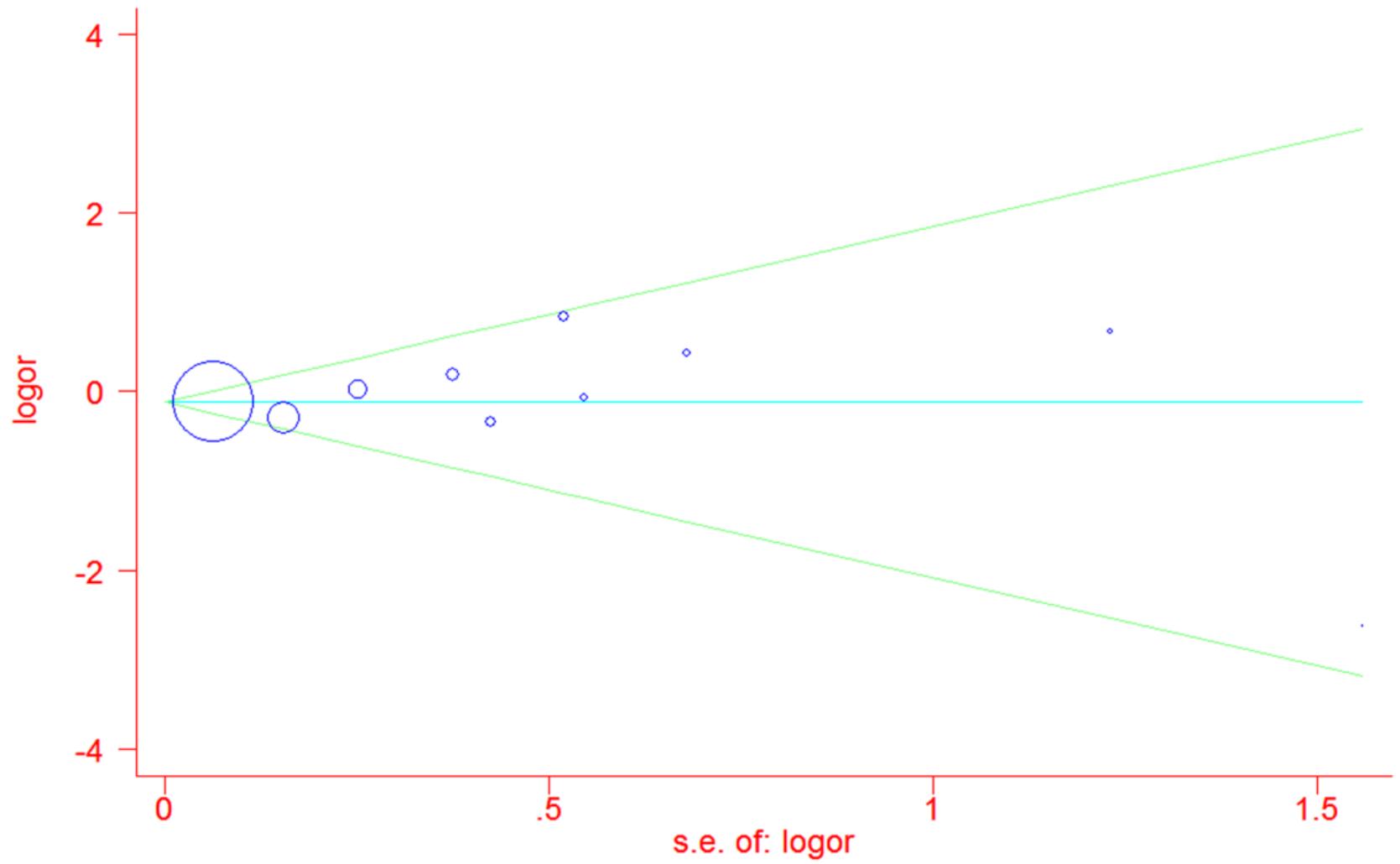

B

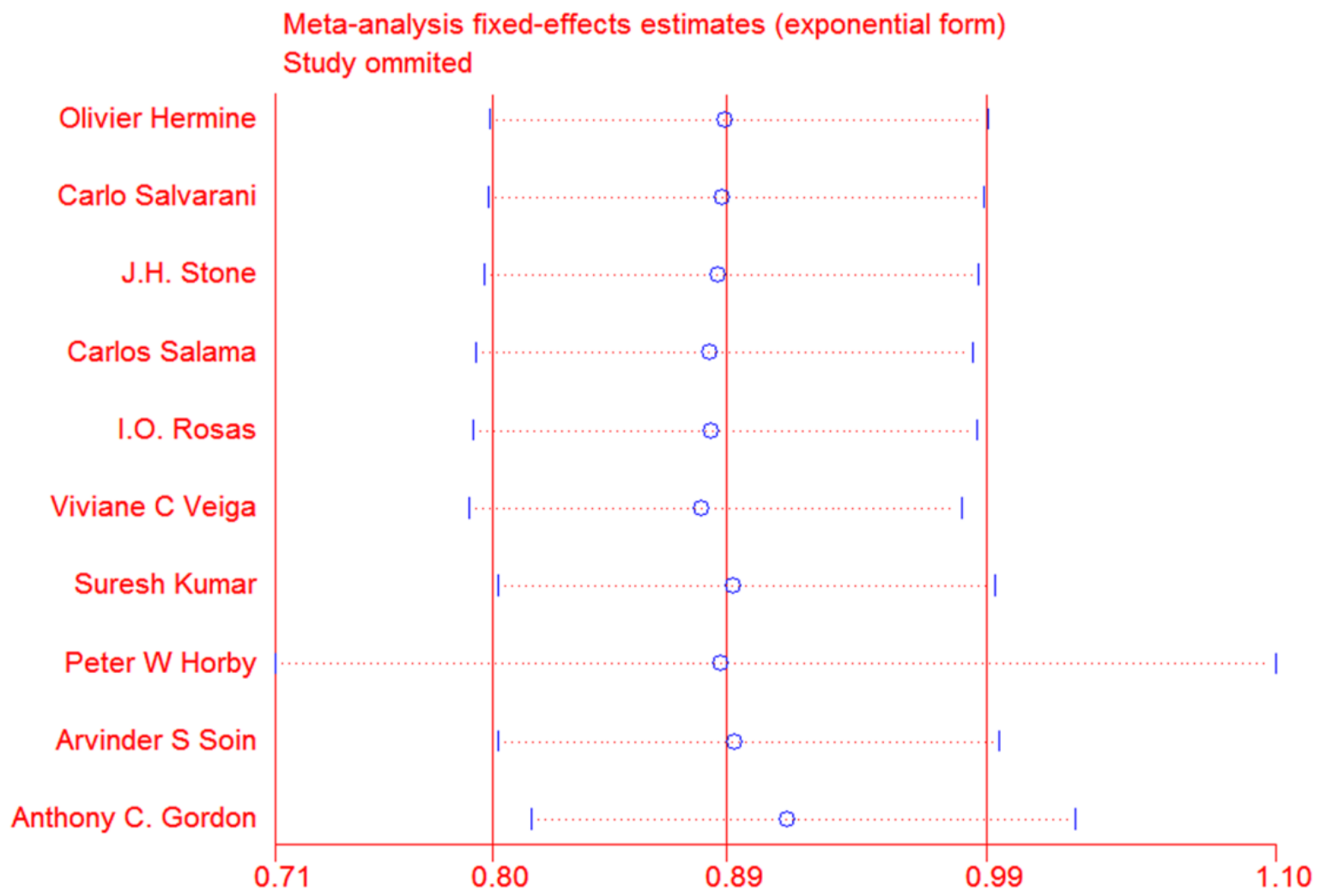

Supplementary Figure 2. Association of tocilizumab with all-cause mortality (A) funnel plot to assess the publication bias of the metaanalysis (B) sensitivity analysis. 


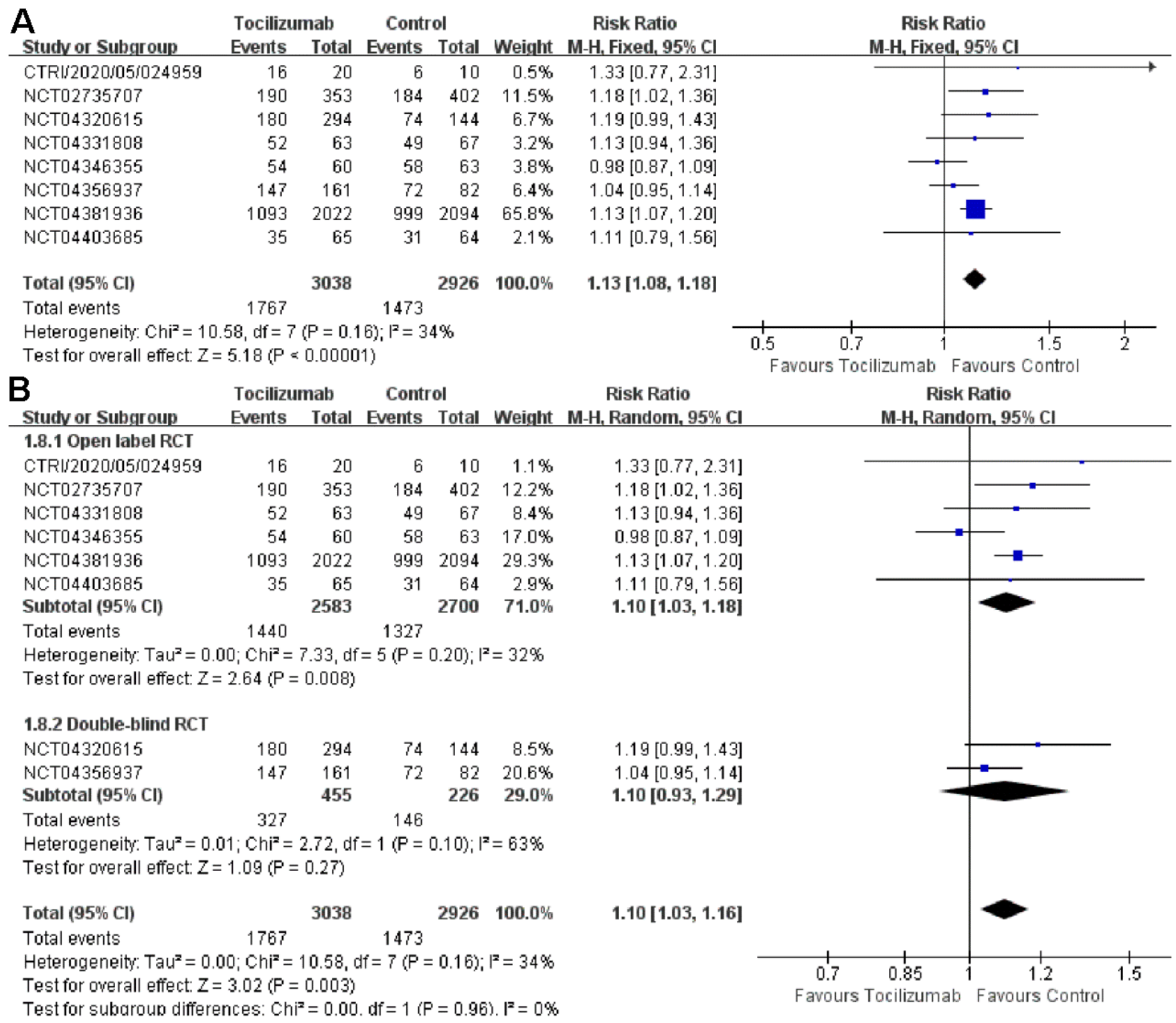

Supplementary Figure 3. Association of tocilizumab with discharge (A) all RCTs (B) study type.

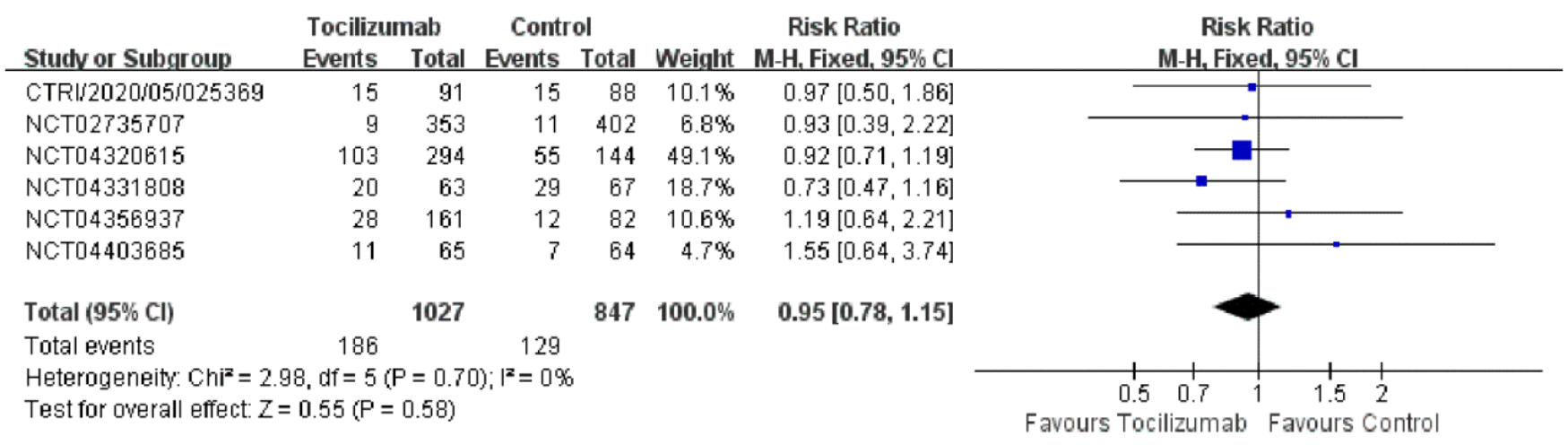

Supplementary Figure 4. Association of tocilizumab with patients of serious adverse events. 


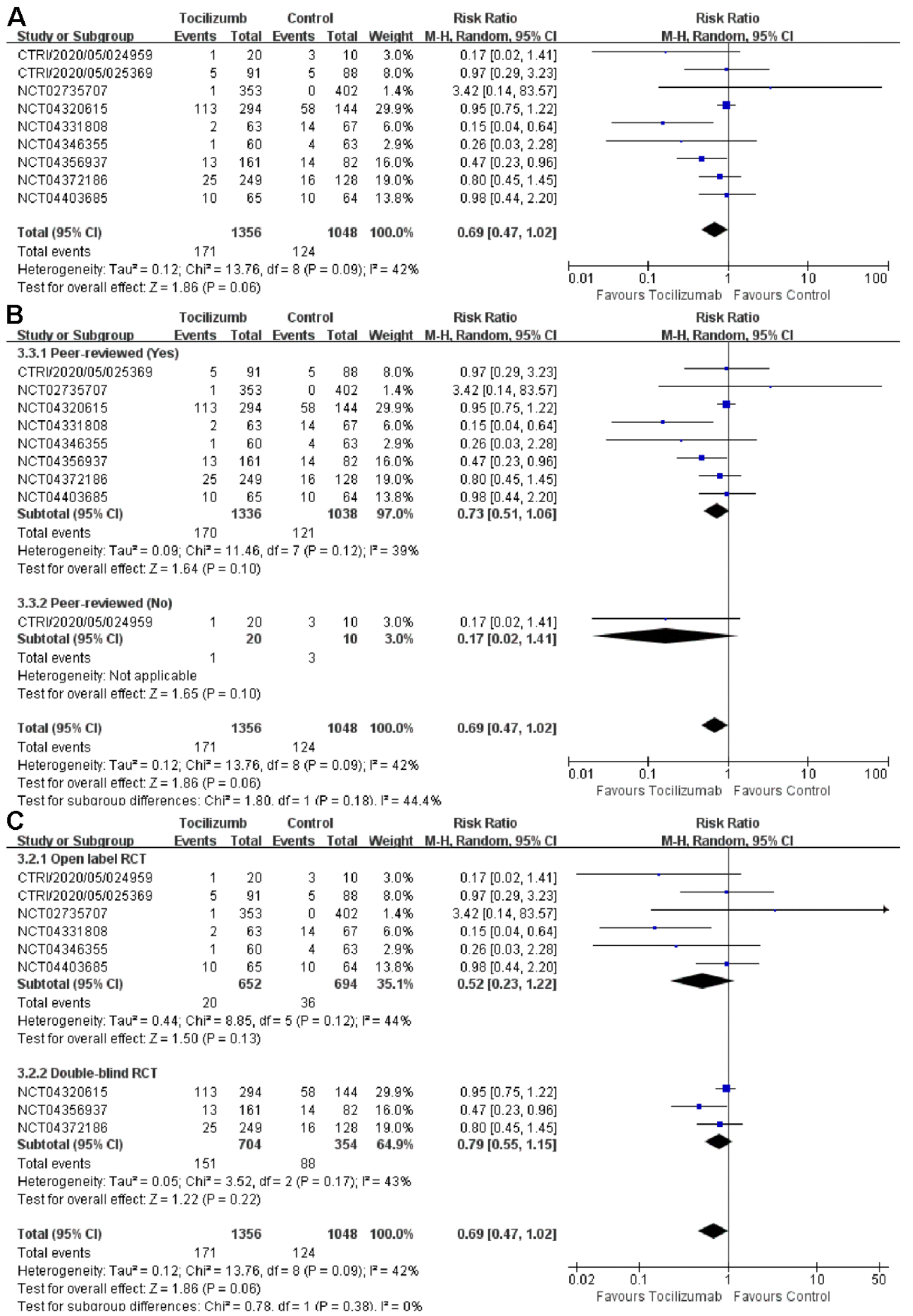

Supplementary Figure 5. Association of tocilizumab with secondary infections risk (A) all RCTs (B) peer-reviewed (C) type of control. 


\section{Supplementary Table}

Supplementary Table 1. Patient baseline characteristics of 8 RCTs in the meta-analysis.

\begin{tabular}{|c|c|c|c|c|c|c|c|c|c|c|c|}
\hline Author & & $\begin{array}{c}\text { Olivier } \\
\text { Hermine }\end{array}$ & $\begin{array}{c}\text { Carlo } \\
\text { Salvarani }\end{array}$ & J.H. Stone & $\begin{array}{c}\text { Carlos } \\
\text { Salama }\end{array}$ & I.O. Rosas & $\begin{array}{l}\text { Viviane } \mathbf{C} \\
\text { Veiga }\end{array}$ & $\begin{array}{l}\text { Suresh } \\
\text { Kumar }\end{array}$ & $\begin{array}{l}\text { Arvinder } \\
\text { S Soin }\end{array}$ & $\begin{array}{c}\text { Anthony } \\
\text { C. } \\
\text { Gordon } \\
\end{array}$ & $\begin{array}{c}\text { Peter W } \\
\text { Horby }\end{array}$ \\
\hline $\begin{array}{l}\text { Trial } \\
\text { registration }\end{array}$ & & $\begin{array}{c}\text { NCT } \\
04331808\end{array}$ & $\begin{array}{c}\text { NCT } \\
04346355\end{array}$ & $\begin{array}{c}\text { NCT } \\
04356937\end{array}$ & $\begin{array}{c}\text { NCT } \\
04372186\end{array}$ & $\begin{array}{c}\text { NCT } \\
04320615\end{array}$ & $\begin{array}{c}\text { NCT } \\
04403685\end{array}$ & $\begin{array}{c}\text { CTRI/2020/0 } \\
5 / 024959\end{array}$ & $\begin{array}{c}\text { CTRI/202 } \\
0 / 05 / 0253 \\
69\end{array}$ & $\begin{array}{c}\text { NCT } \\
02735707\end{array}$ & $\begin{array}{c}\text { NCT } \\
04381936\end{array}$ \\
\hline \multirow{2}{*}{$\begin{array}{l}\text { Treatment since } \\
\text { symptom onset d }\end{array}$} & Tocilizumab & $\begin{array}{c}10(7-13) \\
(n=62)\end{array}$ & $\begin{array}{c}7.0 \\
(4.0-11.0)\end{array}$ & $\begin{array}{c}9.0 \\
(6.0-13.0)\end{array}$ & & $\begin{array}{l}12.1 \pm 6.6 \\
(n=291)\end{array}$ & $10.0 \pm 3.1$ & & & & $9(7-13)$ \\
\hline & Control & $\begin{array}{c}10(8-13) \\
(n=66)\end{array}$ & $\begin{array}{c}8.0 \\
(6.0-11.0)\end{array}$ & $\begin{array}{c}10.0 \\
(7.0-13.0)\end{array}$ & & $\begin{array}{l}11.4 \pm 6.9 \\
(n=143)\end{array}$ & $9.5 \pm 3.0$ & & & & $10(7-14)$ \\
\hline \multirow{2}{*}{ Age } & Tocilizumab & $\begin{array}{c}64.0 \\
(57.1-74.3)\end{array}$ & $\begin{array}{c}61.5 \\
(51.5-73.5)\end{array}$ & $\begin{array}{c}61.6 \\
(46.4-69.7)\end{array}$ & $56.0 \pm 14.3$ & $60.9 \pm 14.6$ & $57.4 \pm 15.7$ & $49.55 \pm 12.49$ & $\begin{array}{c}56 \\
(47-63)\end{array}$ & $61.5 \pm 12.5$ & $63.3 \pm 13.7$ \\
\hline & Control & $\begin{array}{c}63.3 \\
(57.1-72.3)\end{array}$ & $\begin{array}{c}60.0 \\
(54.0-69.0)\end{array}$ & $\begin{array}{c}56.5 \\
(44.7-67.8)\end{array}$ & $55.6 \pm 14.9$ & $60.6 \pm 13.7$ & $57.5 \pm 13.5$ & $48.30 \pm 14.62$ & $\begin{array}{c}54 \\
(43-63)\end{array}$ & $61.1 \pm 12.8$ & $63.9 \pm 13.6$ \\
\hline \multirow{2}{*}{$\begin{array}{l}\text { Gender } \\
\text { (Male/Female) }\end{array}$} & Tocilizumab & $44 / 19$ & $40 / 20$ & $96 / 65$ & $150 / 99$ & $205 / 89$ & $44 / 21$ & $19 / 1$ & $76 / 15$ & $261 / 92$ & $1335 / 687$ \\
\hline & Control & $44 / 23$ & $37 / 29$ & $45 / 37$ & $73 / 55$ & $101 / 43$ & $44 / 20$ & $7 / 3$ & $76 / 12$ & $283 / 119$ & $1437 / 657$ \\
\hline \multirow{2}{*}{ Hypertension } & Tocilizumab & & 27 & 80 & & 178 & 30 & & 36 & & \\
\hline & Control & & 29 & 38 & & 94 & 34 & & 34 & & \\
\hline \multirow{2}{*}{ Diabetes } & Tocilizumab & $20(n=61)$ & 10 & 45 & & 105 & 22 & & 31 & & 569 \\
\hline & Control & $23(n=67)$ & 9 & 30 & & 62 & 20 & & 43 & & 600 \\
\hline \multirow{2}{*}{ Cardiac disease } & Tocilizumab & $20(n=61)$ & & 17 & & 88 & 4 & & 15 & & 435 \\
\hline & Control & $20(n=67)$ & & 7 & & 35 & 3 & & 12 & & 497 \\
\hline \multirow{2}{*}{$\begin{array}{l}\text { Pulmonary } \\
\text { disease }\end{array}$} & Tocilizumab & $3(n=61)$ & 2 & 15 & & 49 & 2 & & 1 & & 473 \\
\hline & Control & $3(n=67)$ & 2 & 7 & & 22 & 2 & & 2 & & 484 \\
\hline \multirow{2}{*}{$\begin{array}{l}\text { Chronic kidney } \\
\text { disease }\end{array}$} & Tocilizumab & $5(n=61)$ & & 29 & & & 5 & & 4 & & 118 \\
\hline & Control & $13(n=67)$ & & 13 & & & 1 & & 4 & & 99 \\
\hline \multirow{2}{*}{ Cancer } & Tocilizumab & $4(n=61)$ & & 22 & & & 5 & & & & \\
\hline & Control & $5(n=67)$ & & 8 & & & 5 & & & & \\
\hline \multirow{2}{*}{ Asthma } & Tocilizumab & $5(n=61)$ & & 15 & & & 4 & & & & \\
\hline & Control & $3(n=67)$ & & 7 & & & 1 & & & & \\
\hline \multirow{2}{*}{ Liver disease } & Tocilizumab & & & & & 6 & & & & & 14 \\
\hline & Control & & & & & 2 & & & & & 10 \\
\hline \multirow{2}{*}{$\begin{array}{l}\text { Body mass } \\
\text { index(BMI) }\end{array}$} & Tocilizumab & $\begin{array}{c}27.9 \\
(23.3-30.8) \\
(n=46)\end{array}$ & & $\begin{array}{c}29.9 \\
(26.0-34.2)\end{array}$ & $32.0 \pm 7.9$ & & & & & & \\
\hline & Control & $\begin{array}{c}27.4 \\
(24.5-31.3) \\
(n=46)\end{array}$ & & $\begin{array}{c}30.2 \\
(25.7-33.8)\end{array}$ & $33.1 \pm 7.2$ & & & & & & \\
\hline \multirow{2}{*}{$\begin{array}{l}\text { Obesity } \\
(\mathrm{BMI} \geq 30)\end{array}$} & Tocilizumab & & 16 & 80 & & 63 & 15 & & & & \\
\hline & Control & & 22 & 42 & & 27 & 16 & & & & \\
\hline
\end{tabular}

